\title{
Erratum to: The potential of remote sensing for monitoring land cover changes and effects on physical geography in the area of Kayisdagi Mountain and its surroundings (Istanbul)
}

\author{
Abdurrahman Geymen • Ibrahim Baz
}

Published online: 23 January 2010

(C) Springer Science+Business Media B.V. 2010

Erratum to: Environ Monit Assess (2008) 140:33-42

DOI 10.1007/s10661-007-9844-6

This article has been retracted due to copyright and authorship questions.

The online version of the original article can be found at http://dx.doi.org/10.1007/s10661-007-9844-6.

\footnotetext{
A. Geymen $(\varangle)$

Faculty of Engineering, Department of Geodesy and Photogrammetry Engineering, Erciyes University, 38039, Kayseri, Turkey

e-mail: ageymen@erciyes.edu.tr

I. Baz

Istanbul Metropolitan Municipality, Istanbul, Turkey
} 